\title{
Desain Game Edukasi Berbasis Android pada Materi Logika Matematika
}

\author{
Surya Amami Pramuditya 1¹, Muchammad Subali Noto'), dan \\ Henri Purwono ${ }^{3)}$ \\ 1) Universitas Swadaya Gunung Jati, Jalan Perjuangan No.1, Cirebon; \\ amamisurya@fkip-unswagati.ac.id \\ 2) Universitas Swadaya Gunung Jati, Jalan Perjuangan No.1, Cirebon; msnoto@fkip- \\ unswagati.ac.id \\ 3) Universitas Swadaya Gunung Jati, Jalan Perjuangan No.1, Cirebon; \\ henriipurwono@gmail.com
}

Dikirim: 2 Februari 2018; Diterima: 8 Maret 2018; Dipublikasikan: 25 September 2018 Cara sitasi: Pramuditya, S.A., Noto, M.S., dn Purwono, H. 2018. Desain Game Edukasi Berbasis Android Pada Materi Logika Matematika. JNPM (Jurnal Nasional Pendidikan Matematika) Vol. 2(2), Hal.165-179.

\begin{abstract}
Abstrak. Penggunaan media pembelajaran di sekolah belum dimaksimalkan. Media pembelajaran belum banyak digunakan dalam proses pembelajaran di kelas ataupun pembelajaran mandiri. Penelitian ini bertujuan untuk membuat game edukasi yang valid dan praktis sebagai media pembelajaran matematika. Metode yang digunakan pada penelitian ini adalah metode penelitian pengembangan dengan model ADDIE yang dibatasi hanya sampai tahap ADD. Jenis game yang dibuat adalah game bergaya RPG (Role Play Game). Instrumen yang digunakan dalam penelitian ini adalah lembar validasi dan lembar praktikalitas. Data yang didapat diolah dengan cara statistika deskriptif. Game edukasi matematika berbasis android dibuat melalui tahapan analisis untuk mengetahui kebutuhan siswa. Pada tahapan desain dilakukan pemilihan format media, dan perancangan media. Pada tahap pengembangan dilakukan prngembangan game sebagai media. Hasil yang didapat game edukasi sangat valid dengan rata-rata penilaian sebesar 93,76\% dari jumlah nilai keseluruhan validator. Game edukasi matematika berbasis android yang dibuat juga sangat praktis. Hal ini ditunjukan dengan rata-rata presentase untuk siswa dengan tingkatan kemampuan tinggi sebesar 94,8\%, siswa dengan tingkatan kemampuan sedang sebesar 94,2\%, dan siswa dengan tingkatan kemampuan rendah sebesar $92,2 \%$. Dalam proses pembelajaran game edukasi yang dibuat tidak dapat menggantikan posisi guru dan buku. Buku tetap menjadi sumber utama belajar, dan game edukasi hanya sebagai pelengkap dalam pembelajaran.
\end{abstract}

JNPM (Jurnal Nasional Pendidikan Matematika) Vol. 2, No. 2, Hal. 165-179 p-ISSN 2549-8495, e-ISSN 2549-4937@Prodi Pendidikan Matematika Unswagati Cirebon 
Kata Kunci: Media, Game Edukasi, RPG, Logika Matematika

\begin{abstract}
The use of instructional media in schools has not been maximized. Learning media has not been widely used in the learning process in the classroom or self-learning. This study aims to create a valid educational game and practical as a medium of learning mathematics. The method used in this research is development research method with ADDIE model which is limited only until ADD stage. The type of game created is a RPG (Role Play Game) game. The instruments used in this research are validation sheet and worksheet sheet. The data obtained is processed by means of descriptive statistics. Android-based mathematics education game is made through the stages of analysis to find out the needs of students. At the design stage, media format selection is chosen, and media design. At the development stage is done game development as media. The results obtained educational games are very valid with an average valuation of $93.76 \%$ of the total value of the validator. The android-based mathematics education game created is also very practical. This is indicated by the average percentage for students with high ability level of $94.8 \%$, students with moderate ability level of $94.2 \%$, and students with low ability level of $92.2 \%$. In the educational game learning process created can not replace the position of teachers and books. The book remains the primary source of learning, and educational games are just a complement to learning.
\end{abstract}

Keywords: Media, Educational Games, RPG, Mathematical Logic.

\title{
Pendahuluan
}

Persaingan global menjadikan tiap individu harus memiliki kemampuan bersaing yang tinggi. Trilling dan Fadel (Abidin, 2014) menjelaskan bahwa ada tiga keterampilan utama yang menjadi fokus di abad ke-21 yang pertama adalah keterampilan belajar dan berinovasi, yang kedua adalah keterampilan dalam menguasai media, informasi, dan teknologi, dan kemampuan ketiga yaitu keterampilan berkehidupan dan berkarir. Kurikulum 2013 menjadi salah satu solusi yang diterapkan pemerintah dalam menghadapi kebutuhan tersebut. Salah satunya kemampuan kedua yaitu kemampuan dalam menguasai media, informasi, dan teknologi. Pada kurikulum 2013 mata pelajaran teknologi, informasi, dan komunikasi (TIK) ditiadakan, namun pembelajaran TIK menjadi terintegrasi pada setiap mata pelajaran. Sehingga, setiap guru pengajar memiliki tantangan lebih karena harus menguasai teknologi, informasi dan media, kemudian 
memanfaatkannya dalam pembelajaran di kelas untuk meningkatkan keterampilan siswa. Teknologi saat ini mengalami perkembangan yang sangat pesat, berbagai penemuan yang mempermudah masyarakat dalam menerima informasi dan membantu pekerjaan sehari-hari. Ponsel yang awal mulanya digunaan hanya sebagai alat komunikasi kini dapat digunakan untuk bekerja, media hiburan, dan banyak hal lainnya. Ponsel cerdas atau yang biasa juga disebut smartphone merupakan temuan baru di bidang teknologi dan komunikasi, perangkat kecil yang merupakan perpaduan antara ponsel dan komputer.

Aplikasi yang dikembangkan pada ponsel cerdas harus merupakan apikasi yang bermanfaat, salah satunya untuk pembelajaran. Dalam pengertian yang umum dan sederhana, belajar seringkali diartikan sebagai ativitas untuk memperoeh pengetahuan (Aunurrahman, 2012: 38). Pembelajaran yang semulanya terjadi ketika tatap muka anara guru dan siswa, dengan pengembangan aplikasi android sebagai media pembelajaran siswa dapat belajar tanpa bertatap muka dengan guru. Pembelajaran yang dilakukan harus didukung dengan konten dan media kreatif yang dapat memunculkan minat siswa dalam belajar. Menurut Hamalik (Arsyad, 2015) penggunaan media pembelajaran dalam proses belajar mengajar dapat meningkatkan keinginan dan minat yang baru.

Game edukasi menjadi salah satu solusi yang ditawaran sebagai media pembelajaran yang inovatif. Game edukasi bisa menjadi media pembeajaran yang mengasikan, menyenangkan, memiliki rangkaian dan meyebaban kecaduan. Menurut hasil penelitian Pramuditya, Noto, \& Syaefullah (2017) game edukasi RPG matematika menarik, menyenangkan, dan dapat mengedukasi penggunanya. Menurut Nikensasi, Kuswardayan dan Sunaryono (2012) game edukasi merupakan salah satu tema permainan yang berusaha memberikan nilai edukasi dalam sebuah permainan sehingga permainan yang awalnya hanya berfungsi sebagai media penghibur, akhirnya juga dapat digunakan sebagai media pembelajaran atau pelatihan. Menurut hasil penelitian Widiastuti dan Setiawan (2012) game edukasi sejarah walisongo dapat membuat pengguna tertarik dalam mempelajari sejarah walisongo dan lebih memberikan nuansa yang menyenangkan. 
Sehingga game edukasi dapat menjadi salah satu solusi media pembelajaran yang menyenangkan. Ponsel cerdas dengan sistem operasi android dapat dignakan seagai perangkat untuk mengeksekusi game edukasi tersebut. Game edukasi berbasis andoid dapat menjadi pilihan guru sebagai media pembelajaran yang interaktif.

RPG merupakan salah satu dari jenis atau gaya game yang merupakan singkatan dari role playing game. Ciri utama dari game yang bergaya RPG adalah pemain bermain sebagai tokoh utama dan harus mengikuti cerita yang ada untuk menyelesaikan game tersebut. Para pemain yang bermain game RPG semakin lama akan semakin penasaran dengan cerita yang ada di dalam game sehingga pemain terbawa untuk menyelesaikan game tersebut. Kelebihan dari game edukasi dengan gaya RPG dapat dimanfaatkan dalam mengedukasi para siswa. Siswa yang merasa penasaran untuk mengetahui jalan cerita dari game RPG sekaligus akan membuat siswa mendapatkan pengetahuan pula ketika menyelesaikan game bergaya RPG. Tujuan dari penelitian ini adalah untuk membuat game edukasi jenis RPG yang didalamnya termuat pembelajaran matematika serta mencari kevalidan game yang dibuat serta praktikalitas pengguna game. Materi dan soal-soal yang yang termuat dalam game ini mengenai logika matematika. Materi logika matematika merupakan salah satu materi yang diajarkan di SMA/SMK. Metode penelitian yang digunakan adalah pengembangan dengan menggunakan model ADDIE akan tetapi dibatasi hanya sampai tahap ADD yakni tahap analisis, desain serta pengembangan (develop). Hasil penelitian ini berupa produk game edukasi matematika yang valid dan praktis.

\section{Metode Penelitian}

Metode penelitian yang digunakan adalah metode penelitian pengembangan. Model penelitian yang dipilih adalah model pengembangan ADDIE (Branch, 2011), yaitu model pengembangan yang terdiri dari lima tahapan yang meliputi analisis (analysis), desain (design), pengembangan (development), implementasi (implementation), dan evaluasi (evaluation). Penelitian ini dibatasi sampai tahap pengembangan (development), karena keterbatasan waktu.

1. Analisis (Analysis)

JNPM (Jurnal Nasional Pendidikan Matematika) Vol. 2, No. 2, Hal. 165-179 p-ISSN 2549-8495, e-ISSN 2549-4937@Prodi Pendidikan Matematika Unswagati Cirebon 
Tahap awal yakni melakukan wawancara untuk menganalisis kebutuhan belajar siswa yang dilihat dari gaya belajar siswa serta menganalisis kompetensi yang akan dimuat dalam media game edukasi.

2. Desain (design)

Dilakukan pemilihan format media, pemilihan materi, penyusunan soal tes dalam game serta perancangan desain media secara keseluruhan (story board).

3. Pengembangan (development)

Pada tahap pengembangan dilakukan pembuatan game menggunakan PC, Seluruh komponen yang telah dipersiapkan pada tahap desain, diproduksi menjadi game edukasi. Setelah media game selesai dibuat kemudian menguji kevalidan game oleh 5 orang validator yang terdiri dari 2 validator ahli media, 2 validator ahli materi, dan 1 validator teman sejawat (mahasiswa).

Selain diuji validasi, dilakukan juga uji praktikalitas pengguna oleh 9 orang responden yang merupakan 3 siswa dengan kemampuan tinggi, 3 orang dengan kemampuan sedang, dan 3 orang dengan kemampuan rendah.

\section{Hasil dan Pembahasan}

Tahap Analisis

Untuk mengetahui kebutuhan siswa dalam belajar, dilakukan wawancara dengan guru mata pelajaran matematika dan beberapa siswa. Kebutuhan siswa dilihat melalui gaya belajar. Berdasarkan hasil wawancara yang dilakukan dengan guru mata pelajaran matematika, siswa kesulitan untuk memahami materi logika matematika. Terutama dalam membedakan dari tiap pokok materi seperti negasi, implikasi, dan sub materi lain. Guru sudah mencoba menggunakan media pembelajaran power point dalam proses pembelajaran. Media power point bertujuan untuk menarik minat siswa dan membantu untuk menyampaikan materi pembelajaran. Media power point masih belum mendukung interaksi antara siswa dan media pembelajaran. Hasil wawancara siswa juga menjelaskan bahwa mereka masih mengalami kesulitan untuk membedakan tiap simbol atau lambang yang ada pada logika matematika. Serta mereka lebih tertarik untuk belajar dengan santai dan menyenangkan serta menginginkan penggunaan media pembelajaran. Siswa belajar menggunakan gaya belajar audio dan visual. Siswa belajar dengan mendengarkan penjelasan dari guru, membaca buku dan melihat isi slidepower point.

JNPM (Jurnal Nasional Pendidikan Matematika) Vol. 2, No. 2, Hal. 165-179 p-ISSN 2549-8495, e-ISSN 2549-4937@Prodi Pendidikan Matematika Unswagati Cirebon 
Tahap Desain

Pada tahapan desain dilakukan pemilihan media pembelajaran serta pembuatan rancangan media pembelajaran. Berikut ini tahapan desain dalam penelitian.

a. Pemilihan Format Media

Berdasarkan analisis yang dilakukan penelitian ini menggunakan media pembelajaran dengan format multimedia berjenis visual. Pemilihan jenis media visual didasarkan pada masih sulitnya siswa dalam membedakan lambang-lambang atau simbol matematika yang ada pada materi logika matematika.

b. Pemilihan Media dan Materi Pembelajaran

Berdasarkan analisis yang dilakukan, maka dilakukan pemilihan media pembelajaran berupa game edukasi. Pemilihan game edukasi didasarkan pada sifat game yang menyenangkan dan kemampan dari game untuk mendukung interaksi antara siswa dan media.

Untuk materi yang digunakan adalah materi pernyataan dan kalimat terbuka, negasi suatu pernyataan, negasi kalimat berkuantor dan kalimat majemuk. Maka materi tersebut dipilih karena mengandung lambanglambang didalamnya.

c. Penyusunan tes

Soal tes yang diberikan merupakan soal tes yang terdiri dari 15 soal yang telah diuji tingkat validitas dan reliabilitasnya. Soal yang diberikan mencangkup keempat indikator pembelajaran yang digunakan. Tes yang digunakan berbasis pada game dan bersifat offline, keseluruhan soal tes ada pada game yang dibuat. Dalam tes berlaaku hukuman bagi siswa yang ssalah menjawab soal dan hadiah bagi siswa yang benar dalam menjawab soal. Hadiah yang diberikan bersifat untuk membantu pengguna dalam menyelesaikan game edukasi yang dibuat.

d. Perancangan desain game edukasi (Story Board)

Game dimuulai dari prolog, latar yang digunakan adalah gambar langit sebagai latar utama. Dalam map ini dilakukan pemilihan jenis kelamin karakter, pemberian nama pada karakter, serta petunjuk penggunaan game. Selanjutnya karakter utama akan dibawa kepada tampilan sebuah sekolah. Pada awal game karakter utama akan diperkenalkan kepada bangunan yang ada di sekolah. Pada map tersebut terdapat 8 karakter yang dapat ditemui oleh karakter utama.

JNPM (Jurnal Nasional Pendidikan Matematika) Vol. 2, No. 2, Hal. 165-179 p-ISSN 2549-8495, e-ISSN 2549-4937@Prodi Pendidikan Matematika Unswagati Cirebon 
Misi pertama yang diberikan adalah masuk ke ruang kepala sekolah, di ruang kepala sekolah terdapat 2 karakter yang dapat ditemui oleh karakter utama. Setelah bertemu kepala sekolah, karakter utama akan diperintahkan mencari ruang kelas pertama. Misi karakter utama adalah untuk menemuai pak Alpha, yaitu karakter yang akan menjelaskan materi.

Selanjutnya karakter utama akan diberi misi menemui bu Beta yang ada di ruang kelas ke dua. Bu Beta adalah karakter yang akan menjelaskan materi. Setelah materi didapat karakter utama akan memasuki dugeon sekolah. Pada dugeon sekolah ada 6 karakter yang dapat ditemui oleh karakter utama. Empat diantaranya adalah para master yang akan memberikan penjelasan materi, satu karakter sebagai pemandu, dan satu karakter lainnya akan memberikan pertanyaan.

Setelah berhasil melewati dugeon sekolah, karakter utama akan keluar dari sekolah. Saat keluar dari sekolah terdapat tampilan sekolah secara keseluruhan. Pada map ini tidak ada karakter yang dapat ditemui karakter utama, pada map ini hanya ditujukan untuk karakter utama berjalan dari sekolah menuju ke gedung tempat raja logika. Setelah berjalan ke tempat raja logika, terdapat tampilan gedung tempat raja logika dalam ukuran kecil. Pada map ini tidak ada karakter yang dapat ditemui. Karakter utama diperintahkan untuk masuk ke dalam gedung.

Dalam gedung ada labirin tempat siswa diberikan soal berdasarkan materi yang sudah dipelajari. Pada map ini ada 5 karakter yang dapat ditemui. Setelah melewati labirin pertama ada labirin kedua tempat siswa diberikan soal melanjutkan dari map sebelumnya mengenai materi yang sudah dipelajari. Pada map ini ada 6 karakter yang dapat ditemui

Setelah melewati kedua labirin karakter utama memasusi tempat raja logika. Pada map ini siswa akan diberikan 4 soal trerlebih dahulu sebelum berduel mengalahkan raja logika. Pada map ini ada 3 karakter yang dapat ditemui. Ketika pemain mengalahkan raja logika maka pemain akan menyelesaikan game edukasi dan akan muncul tampilan credit.

3. Tahap Pengembangan

Setelah game dibuat selanjutnya game diproduksi sehingga dapat dioperasikan. Setelah game dapat dioperasikan dilakukan ujicoba pada game. Selanjutnya dilakukan validasi oleh ahli dan praktikalitas oleh siswa sebagai pengguna media.

a. Mendeploy Game

JNPM (Jurnal Nasional Pendidikan Matematika) Vol. 2, No. 2, Hal. 165-179 p-ISSN 2549-8495, e-ISSN 2549-4937@Prodi Pendidikan Matematika Unswagati Cirebon 
Setelah game kita desain, selanjutnya kita lakukan proses deploy. Proses deploy dilakukan agar game yang sudah kita buat bisa kita mainkan pada PC, Smartphone ataupun di web. Pertama klik file pada menubar kemudian klik deployment.



Gambar 4 Deploy Game

Kemudian muncul kotak dialog opsi untuk deployment. Pilih jenis perangkat android, nama dari game, dan lokasi penyimpanan hasil deploy.

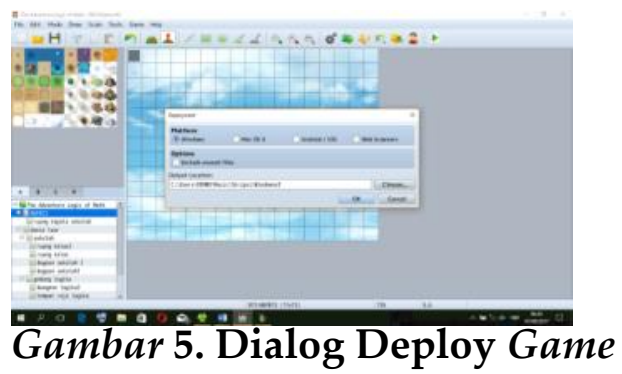

Proses deploy selesai jika sudah muncul tampilan seperti pada gambar.

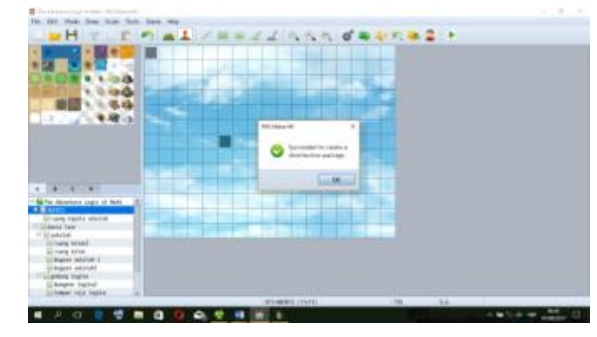

Gambar 6. Deploy Game Sukses

b. Tampilan hasil Game

Pengoprasian game yang dibuat sangat mudah yakni hanya dengan touch pada layar smartphone saja. Berikut berikut ini merupakan tampilan pada game edukasi yang telah dibuat. Pertama ada tampilan awal pada game yang ditunjukan pada gambar 7 . 




Gambar 8. Tampilan Awal

Kemudian akan masuk pada menu. Pada menu terdapat banyak pilihan yakni, new game untuk memulai petualangan baru, continue untuk melanjutkan petualangan yang sudah disimpan sebelumnya, option untuk mengatur opsi game, quit untuk keluar dari game, credits untuk menampilkan tulisan kredit.

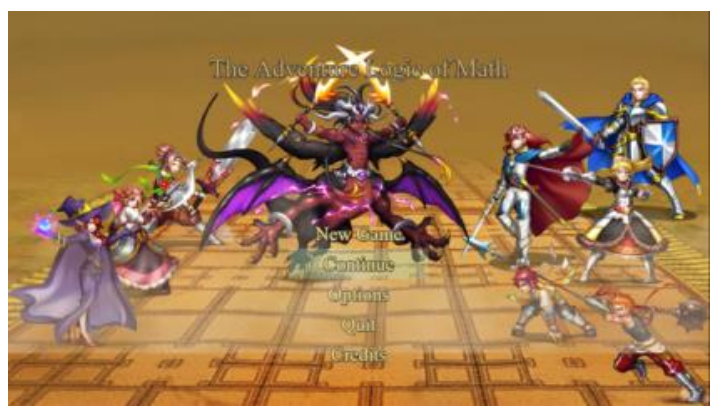

\section{Gambar 10. Menu}

Tokoh utama pada game ini ada laki-laki dan perempuan. Pemain bebas memilih jenis kelamin dari tokoh utama dan memasukan nama dari tokoh utama tersebut



\section{Gambar 11. Pemilihan Jenis Kelamin}




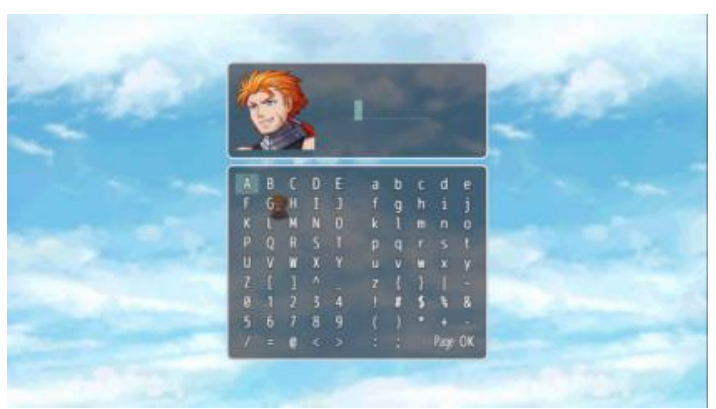

\section{Gambar 12. Memasukan Nama Tokoh Utama}

Pada game yang telah dibuat banyak tokoh lain yang harus ditemui oleh tokoh utama. Setiap tokoh yang ditemui akan memberikan informasi berupa materi ataupun pertanyaan berupa soal matematika. Berikut ini contoh tokoh yang harus ditemui tokoh utama.

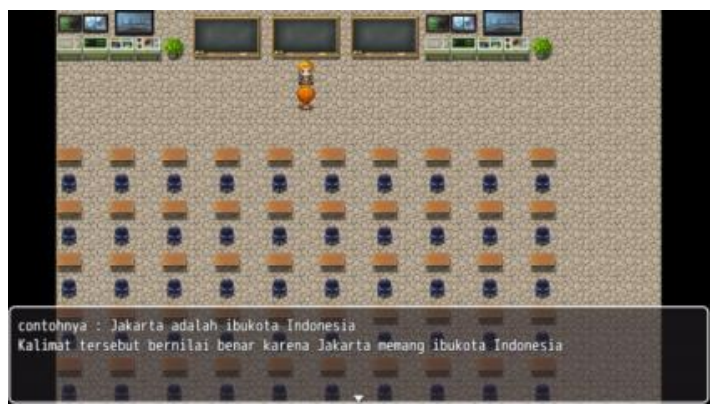

\section{Gambar 13. Pemberian Informasi}

Berikut merupakan contoh pada saat tokoh utama diberikan suatu pertanyaan berupa soal.

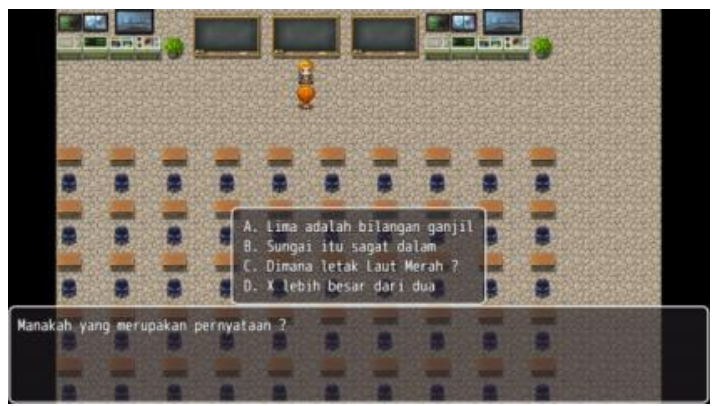

\section{Gambar 14. Pemeberian Soal}

Pada akhir game siswa akan diberikan pertanyaan yang akan mengurangi nyawa dari tokoh utama. Ketrika nyawa tokoh utama habis maka siswa akan mengalami kekalahan dan petualangan berkahir. Ketika nyawa dari karakter utama tidak habis maka pemain akan memenangkan game tersebut.

a. Hasil validasi media 
Validasi media dilakukan kepada 5 orang validator yang diantaranya 2 validator dari dosen program studi matematika, 2 validator dari guru mata pelajaran matematika, dan 1 validator dari mahasiswa (teman sejawat). berikut merupakan hasil validasi media pada tiap aspek dari masing-masing ahli seperti yang ditunjukan pada tabel 1.

\section{Tabel 1. Hasil Validasi Media}

\begin{tabular}{lllllllllll}
\hline & \multicolumn{1}{c}{ Validator } & \multicolumn{1}{c}{ Skor yang Dicapai pada Tiap Aspek } & \multicolumn{3}{c}{ Kriteria Validasi pada Tiap Aspek } \\
\cline { 2 - 12 } & $\mathbf{1}$ & $\mathbf{2}$ & $\mathbf{3}$ & $\mathbf{4}$ & $\mathbf{5}$ & $\mathbf{1}$ & $\mathbf{2}$ & $\mathbf{3}$ & $\mathbf{4}$ & $\mathbf{5}$ \\
\hline Validator 1 & 7 & 8 & 10 & 6 & 25 & $87,5 \%$ & $100 \%$ & $83,3 \%$ & $75 \%$ & $89,2 \%$ \\
Validator 2 & 8 & 8 & 11 & 7 & 25 & $100 \%$ & $100 \%$ & $91,7 \%$ & $87,5 \%$ & $89,2 \%$ \\
Validator 3 & 8 & 8 & 11 & 8 & 27 & $100 \%$ & $100 \%$ & $91,7 \%$ & $100 \%$ & $96,4 \%$ \\
Validator 4 & 8 & 8 & 11 & 7 & 27 & $100 \%$ & $100 \%$ & $91,7 \%$ & $87,5 \%$ & $96,4 \%$ \\
Validator 5 & 8 & 8 & 12 & 7 & 27 & $100 \%$ & $100 \%$ & $100 \%$ & $87,5 \%$ & $96,4 \%$ \\
\hline
\end{tabular}

Keterangan :

Aspek 1: Relevansi

Aspek 2: Alur Materi

Aspek 3: Penyajian Game

Aspek 4: Unsur Kebahasaan

Aspek 5: Unsur Game

b. Hasil praktikalitas pengguna

Uji praktikalitas pengguna dilakukan kepada 9 siswa. Terdiri dari 3 orang siswa dengan kemampuan tinggi, 3 orang siswa dengan kemampuan sedang, dan 3 orang siswa dengan kemampuan rendah. Berikut merupakan hasil praktikalitas pengguna secara keseluruhan seperti yang ditunjukan pada tabel 2.

Tabel 2. Hasil Praktikalitas Pengguna

\begin{tabular}{ccccccccc}
\hline \multirow{2}{*}{ Penilai } & \multicolumn{2}{c}{ Skor yang Dicapai pada Tiap Aspek } & \multicolumn{3}{c}{ Kriteria Praktikalitas pada Tiap Aspek } \\
\cline { 2 - 9 } & $\mathbf{1}$ & $\mathbf{2}$ & $\mathbf{3}$ & $\mathbf{4}$ & $\mathbf{1}$ & $\mathbf{2}$ & $\mathbf{3}$ & $\mathbf{4}$ \\
\hline S-1 & 8 & 8 & 21 & 8 & $100 \%$ & $100 \%$ & $87,5 \%$ & $100 \%$ \\
S-2 & 8 & 7 & 22 & 8 & $100 \%$ & $87,5 \%$ & $91,7 \%$ & $100 \%$ \\
S-3 & 8 & 8 & 24 & 6 & $100 \%$ & $100 \%$ & $100 \%$ & $75 \%$ \\
S-4 & 7 & 7 & 22 & 7 & $87,5 \%$ & $87,5 \%$ & $91,7 \%$ & $87,5 \%$ \\
S-5 & 8 & 7 & 23 & 8 & $100 \%$ & $87,5 \%$ & $95,8 \%$ & $100 \%$ \\
S-6 & 8 & 7 & 23 & 8 & $100 \%$ & $87,5 \%$ & $95,8 \%$ & $100 \%$ \\
S-7 & 7 & 7 & 22 & 8 & $87,5 \%$ & $87,5 \%$ & $91,7 \%$ & $100 \%$ \\
S-8 & 7 & 7 & 23 & 8 & $87,5 \%$ & $87,5 \%$ & $95,8 \%$ & $100 \%$ \\
S-9 & 7 & 7 & 22 & 7 & $87,5 \%$ & $87,5 \%$ & $91,7 \%$ & $87,5 \%$ \\
\hline
\end{tabular}

Keterangan:

Aspek 1: Kemudahan

JNPM (Jurnal Nasional Pendidikan Matematika) Vol. 2, No. 2, Hal. 165-179 p-ISSN 2549-8495, e-ISSN 2549-4937@Prodi Pendidikan Matematika Unswagati Cirebon 
Aspek 2: Bahasa

Aspek 3: Konten game

Aspek 4: Unsur Edukasi dan Kepuasan

Hasil penelitian didapat bahwa uji validasi game yang dilakukan oleh lima orang validator memperoleh nilai kriteria validasi sangat tinggi. Hal ini dibuktikan oleh hasil validasi tiap aspek, bahkan untuk aspek alur materi memperoleh hasil validasi maksimum. Aspek alur materi mendapat nilai maksimum karena alur materi yang dibuat disesuaikan agar materi yang ada pada game runtut dan mengalir mulai dari materi yang sederhana menuju materi yang kompleks. Hal itu dilakukan agar pengguna mudah dalam mempelajari dan memahami materi pembelajaran. Aspek yang memiliki nilai tinggi ke dua adalah aspek relevansi, aspek relevansi mendapat nilai sempurna untuk empat validator dan $87,5 \%$ dari satu validator. Materi dan soal pada game dibuat relevan dengan kompetensi yang harus dikuasai siswa. Aspek relevansi tidak mendapat nilai sempurna dari semua validator, validator pertama memberikan nilai $87,5 \%$. Hal ini dikarenakan belum ada soal untuk satu materi yang dipelajari.Aspek yang memiliki nilai tinggi berikutnya adalah aspek penyajian game dalam aspek ini empat validator memberikan nilai diatas $90 \%$ sementara untuk satu validator memberikan nilai $83,7 \%$. Hal ini dikarenakan dalam penyajiann game edukasi masih belum sepenuhnya membuat siswa membangun pengetahuannya sendiri. Pengguna atau siswa masih harus mendapatkan bimbingan untuk mempelajari materi.

Aspek berikutnya adalah aspek unsur game, pada aspek ini dilakukan penilaian tentang semua yang terkandung pada game. Pada aspek ini tidak ada validator yang memberikan penilaian maksimum, namun untuk tiga validator memberikan penilaian diatas $90 \%$ dan dua validator lainnya memeberikan penilaian 89,2 \%. Pada unsur game secara keseluruhan memang sudah baik namun validator menilai perintah yang digunakan pada game masih kurang mudah untuk dipahami. Hal ini dikarenakan terbatasnya perintah yang diberikan hanya dalam bentuk tulisasn saja, game yang dibuat belum mendukung perintah seacara lisan. Game juga belum mendukung adanya mini map untuk mempermudah pencarian lokasi. Aspek yang mendapatkan nilai terendah adalah aspek unsur kebahasaan.

JNPM (Jurnal Nasional Pendidikan Matematika) Vol. 2, No. 2, Hal. 165-179 p-ISSN 2549-8495, e-ISSN 2549-4937@Prodi Pendidikan Matematika Unswagati Cirebon 
Pada aspek ini satu validator memberikan nilai maksimum, tiga validator memeberikan nilai $87,5 \%$ dan satu validator memberikan nilai $75 \%$. Meskipun mendapat niali terendah diantara lima aspek yang dinilai namun unsur kebahasaan tetap masuk kriteria sangat tinggi.

Berdasarkan penilaian kelima aspek didapat bahwa game edukasi sangat valid. Hasil serupa didapatkan oleh Koriaty dan Agustani (2016) saat melakukan validasi pada game edukasi "merencanakan kebutuhan dasar dan spesifikasi". Game edukasi tersebut valid dengan kategori sangat baik. Hasil penelitian Sari dkk (2014) pada media pembelajaran berupa game edukasi berbasis RPG pada materi struktur atom kelas X SMA mendapatkan penilaian validasi sangat baik dari ahli media dan dari guru mata pelajaran. Artinya game eduaksi yang dibuat dapat digunakan sebagai media pembelajaran.

Selain uji validasi, didapat pula hasil uji praktikalitas pengguna yang diujikan pada 9 siswa yang terdiri dari 3 siswa bekemampuan tinggi, 3 siswa berkemampuan sedang, dan 3 siswa berkemampuan rendah. Hasil yang diperoleh bahwa nilai praktikalitasnya sangat tinggi, artinya pengguna mengatakan bahwwa game yang dibuat oleh peneliti sangat praktis. Hasil praktikalitas pada kelompok siswa berkemampuan tinggi memiliki nilai lebih tinggi dibandingkan kelompok siswa berkemampuan sedang ataupun kelompok siswa berkemampuan rendah.Dilihat untuk tiap aspek, pada aspek kemudahan kelompok siswa berkemampuan tinggi memberikan nilai maksimum. Sementara itu untuk kelompok siswa berkemampuan sedang memberikan nilai lebih tinggi dari kelompok siswa berkemampuan rendah. Siswa berkemampuan tinggi memberikan nilai maksimum dikarenakan game yang dibuat mudah untuk dioperasikan dan dimainkan, sehingga mereka cepat dalam mengolah informasi yang diberikan oleh game. Pada aspek bahasa kelompok siswa berkemampuan tinggi memberikan nilai paling tinggi. Sementara itu kelompok siswa berkemampuan sedang dan kelompok siswa berkemampuan rendah memberikan nilai yang sama. Namun dari segi penilaian ketiga kelompok siswa memberikan penilaian dalam kriteria tinggi. Ketiga kelompok siswa menyatakan bahasa yang digunakan dapat dipahami. 
Pada aspek konten game ketiga kelompok siswa memberikan penilaian yang tidak jauh berbeda. Kelompok siswa berkemampuan sedang memebrikan penilaian sedikit lebih besar dari kelompok siswa berkemampuan tinggi dan kelompok siswa berkemampuan rendah. Ketiga kelompok siswa menyatakan konten yang ada di dalam game sudah sangat baik. Salah satu fungsi media Pada aspek unsur edukasi dan kepuasan kelompok siswa berkemampuan sedang dan kelompok siswa berkemampuan rendah memberikan penilaian yang sama. Kedua kelompok tersebut memberikan penilaian diatas kelompok siswa berkemampuan tinggi. Pada aspek ini penilaian diberikan untuk interaktisi pada media dan kepuasan game. Pada kepuasan, penilaian diberikan secara subjektif sehingga siswa berkemampuan tinggi belum tentu puas dalam memainkan game. Menurut ketiga metode yang dikemukakan.

Berdasarkan penilaian keempat aspek didapat media pembelajaran praktis. Hasil yang tidak jauh berbeda juga didapat pada penelitian Nikensari dkk (2012) saat melakukan uji praktikalitas pengguna yang menyatakan bahwa hasil uji coba pengguna game "Pendekar Pintar" memiliki hasil praktis dari uji coba 17 orang responden. Artinya game edukasi yang dibuat dapat digunakan dengan baik oleh pengguna.

Dari hasil uraian diatas, dapat disimpulkan bahwa hasil validasi media dari kelima validator memperoleh nilai sangat tinggi dan hasil praktikalitas pengguna oleh sembilan orang penilai juga memperoleh nilai yang sangat tinggi maka game edukasi yang peneliti buat ini dinyatakan valid dan praktis. Artinya menurut para ahli dan pengguna, game edukasi dapat digunakan sebagai media pembelajaran matematika.

\section{Simpulan dan Saran}

Berdasarkan hasil analisis data penelitian dan pembahasan maka dapat diambil kesimpulan sebagai berikut; game edukasi matematika berbasis android dibuat melalui tahap analisis kebutuhan siswa, desain media pembelajaran dan pengembangan game sebagai media. Hasil validasi game edukasi sangat valid. Hal ini ditunjukan dengan rata-rata presentase sebesar 97,12\% dari jumlah nilai keseluruhan validator ahli media dan ahli materi. Game edukasi matematika berbasis android sangat praktis. Hal ini 
ditunjukan dengan rata-rata presentase untuk siswa dengan tingkatan kemampuan tinggi sebesar 94,3\%, siswa dengan tingkatan kemampuan sedang sebesar 92,2\%, dan siswa dengan tingkatan kemampuan rendah sebesar $92,2 \%$.

\section{Daftar Pustaka}

Abidin, Y. 2014. Desain Sistem Pembelajaran dalam Konteks Kurikulum 2013. Bandung: PT Refika Aditama

Arsyad, A. 2015. Media Pembelajaran. Jakarta: PT Raja Grafindo Persada.

Aunurrahman. 2012. Belajar dan Pembelajaran. Bandung: Alfabeta.

Branch, R.M. 2011. Instructional Design: The ADDIE Approach. London: Springer.

Koriaty, S \& Agustani, M. D. 2016.Pengembangan Model Pembelajaran Game Edukasi Untuk Meningkatkan Minat Siswa Kelas X TKJ SMK Negeri 7 Ponitianak. Jurnal Edukasi. 14(2).

Nikensasi, P., Kuswardayan, I. dan Sunaryono, D. 2012. Rancang Bangun Permainan Edukasi Matematika dan Fisika dengan Memanfaatkan Accelorometer dan Physics Engine Box2d pada Android. Jurnal Teknik ITS, $1(1), 255-260$.

Pramuditya, S. A., Noto, M. S., \& Syaefullah, D. 2017. Game Edukasi RPG Matematika. Eduma: Mathematics Education Learning And Teaching, 6(1).

Sari dkk. 2014. Pengembangan Game Edukasi Kimia Berbasis Role Play Game Pada materi Struktur Atom Sebagai Media Pemebelajaran Mandiri Untuk Siswa Kelas X SMA di Kabupaten Purworejo. Jurnal Pendidikan Kimia. 3(2).

Widiastuti, N. I. dan Setiawan, I. 2012. Membangun Game Edukasi Sejarah Walisngo. Jurnal Ilmiah Komputer dan Informatika, 2(1), 41-48. 